\title{
The weight of stakeholders on festival management. The case of music festivals in Italy
}

\author{
Angelo Presenza ${ }^{\mathrm{i}}$ \\ Simone Iocca ii \\ University “G. d’Annunzio” (Italy)
}

\begin{abstract}
Even if events can represent important drivers for local development, it is possible to have a genuine economic and social contribution only when the event is undertaken within a paradigm that emphasizes the importance of complex interactions between the event's proposer and its stakeholders. Inside the event sector, festivals represent a specific sub-field that share time similarities and peculiarities as compared to other typologies. This paper analyzes the Italian context of music festivals and deepens the relationships between the festival organizer and public and private actors using stakeholder management approach. Findings suggest that Italian festivals have a reasonable level of entrepreneurship since the analysis reveals a good predisposition for the use of management practices.
\end{abstract}

Keywords: Music festival; Event management; Stakeholder theory; Stakeholder strategies; Relationships.

Título: El peso de las partes interesadas en la gestión del festival. El caso de los festivales de música en Italia

Resumen: A pesar de que los eventos puedan representar una contribución importante al desarrollo económico y social, esto sólo es posible cuando el evento se realiza bajo un paradigma que haga hincapié en la importancia de las complejas relaciones entre el proponente del evento y las partes interesadas. Dentro del sector de los eventos, los festivales representan un sub-campo que comparte similitudes y particularidades, en contraste con otros tipos de evento. Este trabajo analiza el contexto italiano de los festivales de música y profundiza en las relaciones entre el organizador del festival y los actores públicos y privados, utilizando un enfoque de gestión de partes interesadas. Los resultados sugieren que los festivales italianos tienen un nivel razonable de iniciativa empresarial ya que el análisis revela una buena predisposición para el use de prácticas de gestión.

Palabras clave: Festival de música; Gestión de eventos; Teoría de partes interasadas; Estrategias de partes interesadas; Relaciones.

i Assistant Professor in Organization Design, University “G. d’Annunzio”, presenza@unich.it ii PhD Student in Management \& Business Administration, University “G. d’Annunzio”, s.iocca@unich.it. 


\section{Introduction}

With many shapes and specificity, several potential goals to satisfy and a plethora of stakeholders to involve, festivals are somewhat unique in the events sector (Getz et al., 2010). There is a growing interest in how the organization of festivals can preserve and promote anthropological and cultural heritage, animate specific attractions or entire cities, improve the awareness or image of the destination, provide a competitive marketing advantage, and increase the economic benefits. Due to all these potentialities, Richards (2007) has introduced the term "festivalization" in studying why/how festivals have globally become preferred tools in place marketing and tourism development.

Though festival management reproduces generic concepts and methods of event management, it has been recognized as a distinct sub-field (Andersson and Getz, 2008). Among those who suggest treating festivals as a specific sub-group, Getz et al. (2010) note that many festivals are focused on traditional community celebrations (largely organic, even spontaneous) or on cultural and special themed celebrations. In 1987 Falassi described the festival as "a sacred or profane time of celebration, marked by special observances" for highlighting the importance of this special event in celebrating community values, ideologies, identity and continuity. It is easy to note that inside the category of festivals there is a long list of sub-categories each of which with one or more specificities. Wilson and Udall (1982: 3) proposed seven broad categories (arts festivals; dance, jazz and music festival; harvest and food festivals; shows, fairs and festivals; and sports events), while Getz (2005: 21) defined them as "themed, public celebrations" so as not to create too stringent boundaries that could lead to the exclusion of some typology. Besides, putting a festival in a specific category can become very difficult when there is not an attribute that prevails unequivocally on the others (an example can be a festival that promotes music and enogastronomic products simultaneously). Most of the time the explanations essentially apply to all types of festivals and the object of celebration is often recognizable in the name (Getz, 2005), such as the Umbria Jazz Festival (the most important Italian jazz music festival), which indicates its nature.

Festivals can represent an important driver in increasing the destination attractiveness (Arcodia and Robb, 2000) and this is confirmed in looking at the international market where events have become a worldwide tourism phenomenon (Prentice and Andersen, 2003; Allen et al., 2002; Getz, 2005). Nevertheless, many planned events are still produced with little or no thought given to their tourism appeal or potential. The reasons can be sought in the organizers' specific aims, in the absence of relationships established between events and tourism (Getz, 2008), and in the small size of the organization that can limit the marketing and tourism orientation. Also in this case, festivals, such as any other typologies of event, can provide important benefits like social and recreational opportunities for residents (Reid, 2011).

This study adapts a stakeholder perspective on festival management in a study of music festivals. Dependencies between the festival organizer and its stakeholders will be portrayed as well as relational interaction processes. The purpose is to illustrate how the festival organizers view their dependence to their stakeholders and how they manage their stakeholder relations. The study aims to give some insight into how festivals can successfully handle their stakeholders to ensure festival survival.

The study presents empirical evidences for 48 Italian music festivals, investigated through a structured questionnaire administered directly with an electronic survey.

\section{Literature review}

The Festivals depend on different actors because they have critical resources. There are some that become vital partners and can influence on how to develop the festival. Some of them are so important that it is very difficult to replace them in a short or long-term time perspective. One of the most common reasons for festival failure is insufficient resources (Getz, 2002). Lack of resources can be explained by a weakness of the festival management to attract sponsors and donators and/or a high degree of competition for resources in the events sector. Accordingly, festivals are dependent on support from stakeholders for their survival. A challenge for festival organizers is handling their stakeholders in a way that decreases their dependence in relation to their stakeholders (and thereby decreases the risk of lack of resources).

This premise also highlights the importance for the event sector of stakeholders. The identification of all stakeholders and a review of their agendas will assist event managers in balancing the competing needs, tensions and expectations of all stakeholders 
(Getz et al., 2007). It can also provide an excellent opportunity for improving propensity of local businesses to networking activities that represents a crucial, effective and efficient option in terms of mobilizing resources, information, experience, knowledge and ideas.

An event stakeholder can be defined as “... those persons or groups who can influence the organization, or are influenced by it" (Getz, 2007, p. 92). Getz (1991, p. 15) applies the earlier general definition of stakeholders to festivals and events as: “... those people and groups with a stake in the event and its outcomes, including all groups participating in the event production, sponsors and grant-givers, community representatives, and everyone impacted by the event".

Organizing a festival is executed by a coalition of stakeholders involving public, private, and voluntary organizations; for example the festival organization, artists, sponsors, suppliers, public authorities, tourism traders, etc. The efforts of interacting stakeholders lead to the building of a festival and its image, which is expected to attract visitors.

Interaction among the actors is characterized by both competition and collaboration (Gummesson, 1996). In fact, they compete with each other to obtain the satisfaction of related interest and they should work together (collaborate) to reduce the conflict and to attract visitors to the "festival's product".

Therefore, interaction among actors involves conflicts, such as conflicts over the time of artists' performances (for example a later time may be more attractive than an early time) or conflicts over the best advertising, since a central location is more attractive than a peripheral one. So, actors have different, and sometimes opposing, interests (Wood and Gray, 1991), goals and strategies.

In order to promote specific interests, an individual seeks to reinforce its position of power over other stakeholders involved (Huxham, 1996). Actors with a strong position can have more influence on the development and commercialization of the festival's product, therefore, better opportunities to satisfy their interests. However, actors complement each other: they link complementary products and services to add further commercial value (Cunningham and Culligan, 1990). A festival offering a broad supply of activities is expected to attract more visitors, also from different market segments.

There are different theoretical approaches in dealing with an organization's contextual environment and this paper will focus on the approach of
Stakeholder Theory. The stakeholder approach refers to groups and individuals who can affect the organization, and managerial behavior taken in response to those groups and individuals (Freeman, 1984).

Stakeholder theory focuses on stakeholders and their potential for cooperation or threat from a focal firm's perspective. In this sense, this theory sees the company as an organization from which many agents (stakeholders or groups of interest) request multiple demands that are not always coherent (Donaldson and Preston, 1995). A group or an individual is qualified as a stakeholder if it has a legitimate interest in aspects of the organization's activities and, thus, has either the power to affect the organization's performance and/or has a stake in its performance (Sautter and Leisen, 1999).

Savage et al. (1991) propose their perspective to understand stakeholder's potential to threaten the organization. The capacity, opportunity, and willingness to do so is postulated to be function of the player's relative power and its relevance to a particular issue dealt with. Mitchell et al. (1997) combine the concepts of power with legitimacy and urgency to create a typology to support the analysis of stakeholder relevance. They propose that salience (as perceived by managers) will be positively related to the number of these three attributes that managers perceive the stakeholder to possess.

Stakeholders are not all equal, so it is indispensable for the management of an organization to prioritize them and focus their efforts accordingly. This prioritization requires a basis for analysis. Reid and Arcodia (2002) proposed a conceptual model showing how events are linked to primary and secondary stakeholders. "Primary" stakeholders were defined as those on whom the event is dependent (namely, employees, volunteers, sponsors, suppliers, spectators, attendees, and participants), while "secondary" stakeholders include the host community, government, essential services, media, tourist organizations, and businesses. Another classification is provided by Getz et al. (2007) who group stakeholders into "facilitator" (provides resources and support), "regulator" (usually government agencies), "co-producer" (other organizations and persons who participate in the event), "allies and collaborators" (such as professional associations and tourism agencies), and those impacted (mainly the audience and the community).

Festival and event stakeholder groups may be considered in relation to the power and influence 
that they are perceived to have within a festival or event organization. This can be defined in relation to their roles and the success of festivals and events. Stakeholders may be considered additionally in relation to their impact upon the achievement of a festival's aims. Therefore, the identification and classification of festival stakeholders is essential to the strategic positioning of festivals (Getz, 2005, 2007; Getz et al., 2007). Moreover it is evident that: “... stakeholder analysis and management can be used to build more effective event brands" (Merrilees et al., 2005: 1060).

Once all stakeholders have been identified, it becomes fundamental to individuate the presence of relationships and relative frequency of relationships. The management and continued success of festivals is dependent therefore on those stakeholders who are most involved with the festival organization (Reid and Arcodia, 2002). The analysis of similarities and/or differentiation helps to individuate groups of stakeholders in order to organize appropriate strategies. The Savage et al. (1991)'s typology provides a balanced view of the possible influences - co-operation and threat - and explicitly attempts to place stakeholders in a management context by suggesting appropriate strategies for each type. Those authors prescribe specific management strategies based on a typology that relates a stakeholder's potential to threaten the organization to their potential to cooperate with it. They advocate a "collaborative strategy" where the potential for both cooperation and threat is high. A "defensive strategy" is suggested when the potential for threat is high and the potential for cooperation is low. An "involvement strategy" is prescribed for situations of low potential for threat but high potential for $\mathrm{co}^{-}$ operation. Still a "monitoring strategy" is called for when both the potential for threat and cooperation are low.

It is important to emphasize that the presence of a good stakeholder management approach can also support festivals in responding to possible problems or threats that can arise in the festival organization. Andersson and Getz (2008: 215), for example, in analyzing a sample of live-music festivals in Sweden, provided a list of hypothetical threats and asked respondents to indicate if those had been serious problems. Their research reveals that the most serious problem is "bad weather", followed by "the high cost of entertainment or performers" and "overreliance on one source of money".

\section{Research methodology}

The first step of the research has been to individuate the population of Italian music festivals. The activities have not been quick because a national organization that represents them doesn't exist. Then a complete census of all self-titled "festivals" in Italy was undertaken through several methods such as search of commercial sites specialized on music, tourism regional websites such as those administrated by DMOs, and a Google search with a set of predetermined key-words. Because most of them are small, community-based, spread around all the Country, and are constantly changing as new ones enter while others fail or change in fundamental ways, there is no possible generalizability to the whole population of festivals in Italy. Despite this, a list of 194 festivals has been created.

An email was sent to festivals present in the list inviting them to complete a questionnaire in a webbased survey solution. Allowing for an eight week survey period (October - December, 2010) which included a pre-test on three festivals through a faceto-face interview, a total of 55 questionnaires were returned. After the first month, a reminder call was made to available phone numbers. There were 48 useable questionnaires (a $25.26 \%$ response rate). In our opinion, the final sample size is quite acceptable because it covered a diverse range of Italian music festivals in terms of geographical location, music genre, form, size, funding and number of editions.

The questionnaire is divided into three main sections. The first part asked for general information, such as ownership and control, musical genre prevailing, programme, number of editions, total audience, venues used, staff, revenues and costs. The second part is related to the strategies used in running the event in the previous three years and what degree of success was ascribed to each on a 5-point Likert scale (where $1=$ completely ineffective and 5 = fully effective, or 0 if it did not use the specific strategy). Respondents were also asked to answer statements concerning challenges and threats to their festival. The third part set out a list of the different organizations (public and private). The list was originated and adapted starting from the one provided by Getz et al. (2010). The Interviewee was asked to indicate for each stakeholder the presence of relationships (yes/no), the frequency (daily/weekly/monthly), and the quality ( $1=$ poor to $5=$ excellent). We decided to use also weighted responses to improve the accuracy of answers (ratio 
can vary from $0=$ low use to $4=$ high use). In doing so, further information about relationships between festivals and their stakeholders was gathered asking about the tools used to communicate (e-mail numbers, fax number traded, number phone calls, mails, meeting organized).

\section{Results and discussion}

The sample analyzed consists of festivals of different territories (some are itinerant, that are repeated in the same way, but in different places), from the north to the south of Italy, and taking place at different times during the year.

In relation to the prevailing music style, in the festivals analyzed, $20.84 \%$ are focused on Jazz while $16.67 \%$ on classic and $16.67 \%$ on folk, $14.58 \%$ on rock, $8.33 \%$ on pop, $2.08 \%$ on blues, and $20.83 \%$ on other types of music. The observation of the festivals' names reveals that in $22.92 \%$ of cases there is the word "music" while $47,92 \%$ of the festivals include the music genre in their names. $66.67 \%$ are organized by cultural associations, $6.25 \%$ by foundations, $12.50 \%$ by private companies, and $14.58 \%$ by public bodies such as municipalities. Table 1 contains the longevity and highlights that show how nearly 50\% refers to a festival with a number of editions below 10 . There is a mean of 46.835 spectators while the number of the people involved in the organization is on average 36 .

The number of artists participating in the festival varies depending on the type of event and the proposed musical genre: from a few individuals (in the case of jazz, blues or pop festival) to hundreds of artists (for example, in the case of folk or classic festival).

Looking at the total revenue (figure 2), it emerg- es that the first source is sponsorships followed by public grants. Tickets represent $16 \%$ while merchandising only $1 \%$. In addition, festivals choose sponsorships in $84.62 \%$ of cases, followed by municipal and regional grants (71.79\% and 58.97\%), and tickets $(53.85 \%)$.

Instead, the analysis of expenditure highlights that the ranking is the cachet of the artists $(42.85 \%)$, organizational expenses (37.10\%), marketing expenses $(14.56 \%)$, and other $(5.49 \%)$.

Figure 1 shows that festivals with more editions are characterized by higher values compared with festivals with less editions and it highlights how the gap between revenue and expenditure is very considerable for the youngest festivals while it is almost absent for the other categories.

The stakeholders of a festival were grouped in this way:

- media (television and radio stations, newspapers and magazines);

- music and artists (national and international, music/arts performers/bands and their booking agency);

- public authorities (local authority, government agencies that give grants, police and other public services);

- sponsors (big and small companies that use the festival as a marketing tool);

- suppliers of facilities, food and beverages;

- visitors (trough trading intermediaries);

- tourism traders (hotel, other accommodation, restaurant, associations and clubs);

- independent organizations (that work to organize and promote the festival).

A first analysis shows that festivals perceive a greater dependence on stakeholders that provide funds (public bodies and sponsors) while assigning less weight to logistics and facilities.

\begin{tabular}{lcccc}
$\begin{array}{l}\text { Number of } \\
\text { editions }\end{array}$ & No & \% & Mean spectators & Mean people involved \\
Less than 5 & 9 & $18,75 \%$ & 28.080 & 20 \\
From 5 to 10 & 16 & $33,33 \%$ & 6.447 & 24 \\
From 11 to 15 & 7 & $14,58 \%$ & 33.714 & 41 \\
From 16 to 20 & 5 & $10,42 \%$ & 4.320 & 29 \\
More than 20 & 11 & $22,92 \%$ & 154.739 & 71 \\
\hline
\end{tabular}

Table 1. Number of Festival's Editions 


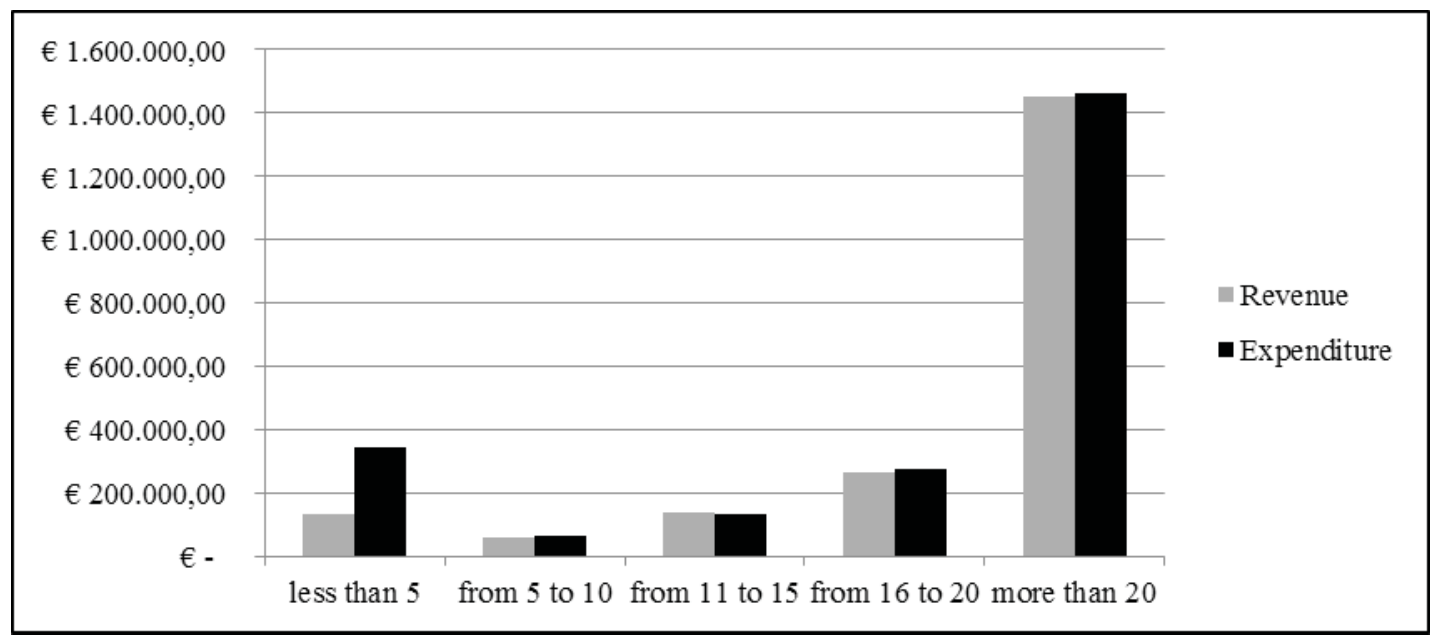

Figure 1. Revenue and Expenditure

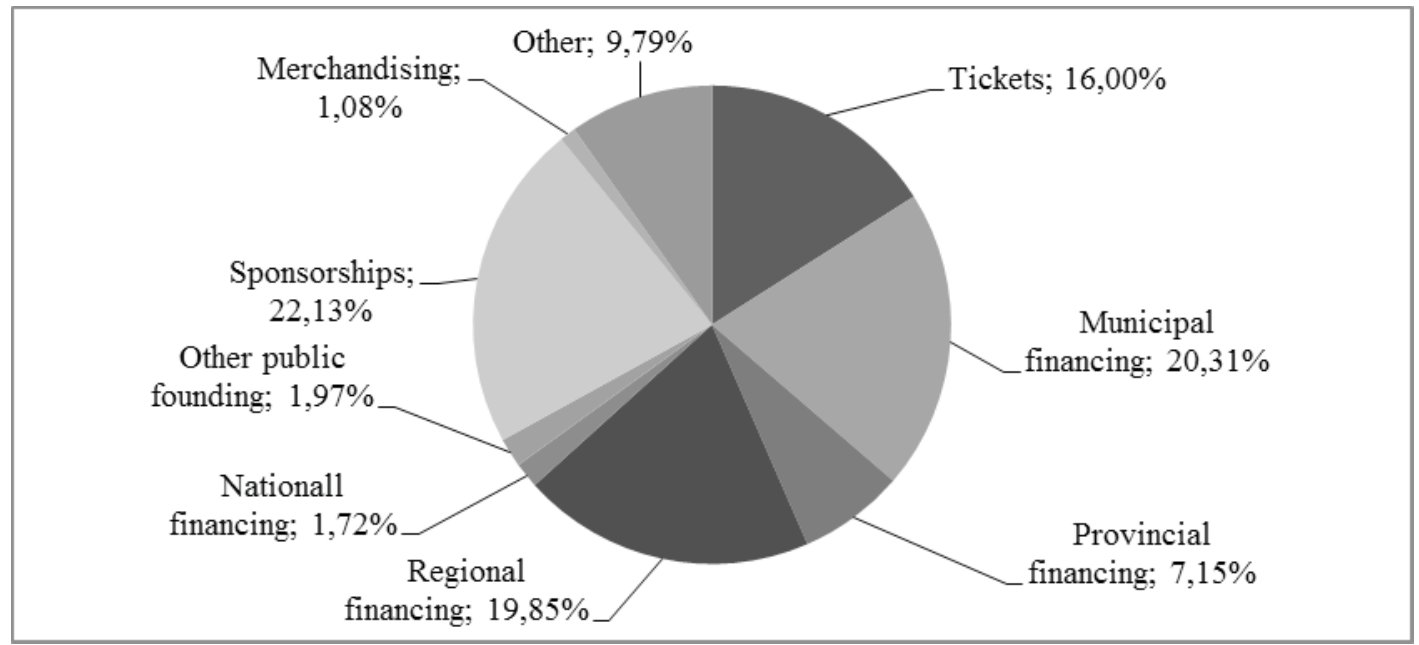

Figure 2. Sources of Revenue and Expenditure

All festivals affirm to have good relationships with stakeholders (in fact, in a range from $1=$ poor to $5=$ very good, the average is 4 ). A deeper analysis of the frequency (daily, weekly, and monthly) and the communication tools (presence of relationships - weighted) demonstrates how relations are not so intensive (table 2).

In fact, reports that focus on the months before the festival usually have a monthly or weekly frequency. Instead, relations are more frequent (daily) in the weeks before the event, such as trading with intermediaries, the media and artists.

Considering the number of festival's editions, interesting reflections emerge on the quantity of relationships that the organization has with its stakeholders (table 3). For the determination of the quantity of reports (low level, medium level or high level), the reference was the number of e-mail, faxes, phone calls, letters and meetings.

Generally, with most of the stakeholders, the intensity level or relationships is medium. In particular, the festivals that have a number of editions over 20 are those with a high level of intensity (in particular with media, artists, sponsors, government agency, local authority, tourism traders and trading intermediaries). This can best be explained if the ability of the organizers and the network of relationships that they have built over the years are 


\begin{tabular}{|c|c|c|c|c|c|c|}
\hline Stakeholder & $\begin{array}{l}\text { Presence } \\
\text { of relation- } \\
\text { ships }\end{array}$ & Daily & Weekly & Monthly & $\begin{array}{c}\text { Presence } \\
\text { of rela- } \\
\text { tionships } \\
\text { (weighted) } \\
\text { From } 0 \text { to } 4\end{array}$ & Quality \\
\hline \multirow{3}{*}{$\begin{array}{l}\text { Media } \\
\text { Other artists (not internation- } \\
\text { al) } \\
\text { Local authority }\end{array}$} & $94.74 \%$ & $17.14 \%$ & $37.14 \%$ & $45.72 \%$ & 1.39 & 3.68 \\
\hline & $94.74 \%$ & $5.71 \%$ & $45.71 \%$ & $48.58 \%$ & 1.32 & 4.21 \\
\hline & $92.11 \%$ & $10.81 \%$ & $40.54 \%$ & $48.65 \%$ & 1.54 & 3.83 \\
\hline International artists & $84.21 \%$ & $15.62 \%$ & $37.50 \%$ & $46.88 \%$ & 1.11 & 4.32 \\
\hline Facilities & $81.58 \%$ & $3.33 \%$ & $33.33 \%$ & $63.34 \%$ & 0.97 & 4.13 \\
\hline Artist booking agency & $78.95 \%$ & $9.68 \%$ & $54.84 \%$ & $35.48 \%$ & 1.12 & 3.81 \\
\hline Our major corporate sponsors & $76.32 \%$ & $3.45 \%$ & $17.24 \%$ & $79.31 \%$ & 1.00 & 3.79 \\
\hline \multirow{3}{*}{$\begin{array}{l}\text { Our small corporate sponsors } \\
\text { Government agencies that } \\
\text { give us grants } \\
\text { Tourism traders }\end{array}$} & $73.68 \%$ & $0.00 \%$ & $14.29 \%$ & $85.71 \%$ & 0.89 & 3.74 \\
\hline & $65.79 \%$ & $7.41 \%$ & $14.81 \%$ & $77.78 \%$ & 0.93 & 3.56 \\
\hline & $57.89 \%$ & $9.52 \%$ & $28.57 \%$ & $61.91 \%$ & 0.74 & 3.71 \\
\hline Food and beverage providers & $55.26 \%$ & $0.00 \%$ & $36.84 \%$ & $63.16 \%$ & 0.62 & 4.11 \\
\hline \multirow{3}{*}{$\begin{array}{l}\text { Trading intermediaries } \\
\text { Police and other public ser- } \\
\text { vices } \\
\text { Independent organizations }\end{array}$} & $52.63 \%$ & $25.00 \%$ & $50.00 \%$ & $25.00 \%$ & 0.49 & 3.95 \\
\hline & $52.63 \%$ & $0.00 \%$ & $9.52 \%$ & $90.48 \%$ & 0.48 & 3.95 \\
\hline & $42.11 \%$ & $6.25 \%$ & $37.50 \%$ & $56.25 \%$ & 0.65 & 3.93 \\
\hline
\end{tabular}

Table 2. Stakeholders and Relationships

\begin{tabular}{lccccc} 
& \multicolumn{5}{c}{ No. of festival's editions } \\
\cline { 2 - 6 } Stakeholder & less & from 5 & from 11 & from 16 & more \\
than 5 & to 10 & to 15 & to 20 & than 20 \\
\hline Facilities & $\mathbf{M}$ & $\mathbf{M}$ & $\mathbf{M}$ & $\mathbf{M}$ & $\mathbf{M}$ \\
Food and beverages & $\mathbf{M}$ & $\mathbf{M}$ & $\mathbf{M}$ & $\mathbf{M}$ & $\mathbf{M}$ \\
Media & $\mathbf{M}$ & $\mathbf{M}$ & $\mathbf{M}$ & $\mathbf{M}$ & $\mathbf{H}$ \\
Other artists (not international) & $\mathbf{M}$ & $\mathbf{M}$ & $\mathbf{M}$ & $\mathbf{M}$ & $\mathbf{H}$ \\
International artists & $\mathbf{M}$ & $\mathbf{M}$ & $\mathbf{M}$ & $\mathbf{M}$ & $\mathbf{H}$ \\
Artist booking agency & $\mathbf{M}$ & $\mathbf{M}$ & $\mathbf{M}$ & $\mathbf{M}$ & $\mathbf{H}$ \\
Our major corporate sponsors & $\mathbf{M}$ & $\mathbf{M}$ & $\mathbf{M}$ & $\mathbf{M}$ & $\mathbf{H}$ \\
Government agencies that give & $\mathbf{M}$ & $\mathbf{M}$ & $\mathbf{M}$ & $\mathbf{M}$ & $\mathbf{H}$ \\
us grants & $\mathbf{H}$ & $\mathbf{M}$ & $\mathbf{H}$ & $\mathbf{M}$ & $\mathbf{H}$ \\
Local authority & $\mathbf{M}$ & $\mathbf{M}$ & $\mathbf{L}$ & $\mathbf{M}$ & $\mathbf{M}$ \\
Independent organizations & $\mathbf{M}$ & $\mathbf{M}$ & $\mathbf{L}$ & $\mathbf{M}$ & $\mathbf{H}$ \\
Our small corporate sponsors & $\mathbf{M}$ & $\mathbf{L}$ & $\mathbf{M}$ & $\mathbf{M}$ & $\mathbf{H}$ \\
Tourism traders & $\mathbf{L}$ & $\mathbf{L}$ & $\mathbf{L}$ & $\mathbf{M}$ & $\mathbf{H}$ \\
Trading intermediaries & $\mathbf{L}$ & $\mathbf{L}$ & $\mathbf{L}$ & $\mathbf{M}$ & $\mathbf{M}$ \\
Police and other public services & & & & & \\
\hline
\end{tabular}

Note: $\mathrm{L}=$ Low; $\mathrm{M}=$ Medium; $\mathrm{H}=$ High.

Table 3. Quantity of Relationships 
considered. Observation of the table 3 shows how the festivals with a number of less than 16 editions have a low level of intensity of their relationships in particular with trading intermediaries, police and other public services, independent organizations, small corporate sponsors and tourism traders.

Stakeholder strategies were examined and results are highlighted in table 4. It was asked which strategies had been employed over the past three years, and the perceived degree of success on a scale of five (with $1=$ completely ineffective; 5 (= completely effective; 0 when strategy is not used). Looking at the column "use of the strategy", the most frequently practiced strategies were "worked on creating an identity / image" and "worked on the promotion of brand" with a good perceived degree of success $($ mean $=4)$. These are followed by "worked on the promotion of brand" (degree of success of 4), "developed initiatives in support of the local community" (degree of success of 4 ). While less common strategies include: "supported the collaboration between the sponsors for their mutual benefit" with a sufficient perceived degree of success $($ mean $=3$ ), "got money loan to cover financial losses" (degree of success of 3) and "paid a company to search for new funding sources or sponsors" (degree of success of 2).

The observation of the data shows that the main focus of the festival organizers is to work on the brand and the image of the event, involving the community. While low attention concerns the economic aspects of the organization and management of the event.

Table 5 lists several issues and reveals that almost all are considered strengths. Particularly, the highest rated strengths were "artistic proposal", "period of performance", "location", and "staff", while "ability to manage cash-flow" and "costs" were indicated as weaknesses. Probably, these points of weakness also explain why some festivals are no longer replicated over the years. In fact, the lack of economic resources is the main cause of survival of an event: often, the costs of organization are not properly covered by revenue. The results highlight how among all stakeholders, musicians are the one that receive the higher attention from festival organization, followed by staff.

\begin{tabular}{|c|c|c|c|c|}
\hline & \multicolumn{2}{|c|}{$\begin{array}{c}\text { Use of the } \\
\text { strategy (\%) }\end{array}$} & \multicolumn{2}{|c|}{$\begin{array}{l}\text { If yes, the de- } \\
\text { gree of success }\end{array}$} \\
\hline & No & Yes & Mean & S.D. \\
\hline Worked on creating an identity / image & $2 \%$ & $98 \%$ & 4,36 & 0,78 \\
\hline Worked on the promotion of brand & $12 \%$ & $88 \%$ & 4,03 & 1,01 \\
\hline Developed initiatives in support of the local community & $20 \%$ & $80 \%$ & 4,00 & 1,14 \\
\hline Invested in the creativity to invent new products within the festival & $20 \%$ & $80 \%$ & 3,03 & 1,36 \\
\hline Converted a supplier in a sponsor (to reduce costs) & $30 \%$ & $70 \%$ & 2,86 & 1,33 \\
\hline Worked as a lobby for funding or other benefits & $35 \%$ & $65 \%$ & 2,58 & 1,03 \\
\hline Contacted the media to become official sponsors & $37 \%$ & $63 \%$ & 3,32 & 1,49 \\
\hline $\begin{array}{l}\text { Developed and formalized marketing partnerships with other or- } \\
\text { ganizations }\end{array}$ & $42 \%$ & $58 \%$ & 3,17 & 1,50 \\
\hline Tangible resources shared with other festivals & $47 \%$ & $53 \%$ & 2,71 & 1,35 \\
\hline Taken legal action to register the brand & $57 \%$ & $43 \%$ & 3,82 & 1,38 \\
\hline Provided fund to cover the unexpected (i.e. Insurance rain) & $60 \%$ & $40 \%$ & 2,81 & 1,47 \\
\hline Imitated other festivals / events to keep up with market trends & $60 \%$ & $40 \%$ & 2,50 & 1,03 \\
\hline $\begin{array}{l}\text { Other organizations authorized to use the name and logo of the } \\
\text { festival }\end{array}$ & $67 \%$ & $33 \%$ & 2,00 & 1,22 \\
\hline Supported the collaboration between the sponsors for their mutual & $67 \%$ & $33 \%$ & 3,00 & 1,63 \\
\hline $\begin{array}{l}\text { benefit } \\
\text { Got money to loan to cover financial losses }\end{array}$ & $70 \%$ & $30 \%$ & 3,08 & 1,44 \\
\hline Paid a company to search for new funding sources or sponsors & $77 \%$ & $23 \%$ & 2,44 & 1,51 \\
\hline
\end{tabular}

Table 4. Stakeholder Strategies Employed and Perceived Degree of Success 


\begin{tabular}{lcc}
\hline Issues & Strength (\%) & Weakness (\%) \\
\hline Artistic proposal & $95 \%$ & $5 \%$ \\
Period of performance & $95 \%$ & $5 \%$ \\
Location & $88 \%$ & $12 \%$ \\
Staff & $85 \%$ & $15 \%$ \\
Ability to manage debt & $76 \%$ & $24 \%$ \\
Planning and organization & $68 \%$ & $32 \%$ \\
Reputation & $66 \%$ & $34 \%$ \\
Human Resource management & $66 \%$ & $34 \%$ \\
Event marketing & $65 \%$ & $35 \%$ \\
Relations with the resident population & $58 \%$ & $42 \%$ \\
Resource management (i.e. Equipment, venue) & $57 \%$ & $43 \%$ \\
Involvement of local actors & $53 \%$ & $47 \%$ \\
Ability to manage cash-flow & $34 \%$ & $66 \%$ \\
Ability to manage costs & $32 \%$ & $68 \%$ \\
\hline
\end{tabular}

Table 5. Strength and Weakness of the Music Festival

\section{Conclusions}

The survey has revealed how festivals are variegated and spread around all Italian regions. Therefore it was possible to find around 200 festivals focused on music and it may be that others exist. It is difficult to survey them because among many reasons, the most evident are that a national association does not exist, few of them work all year round, and many are not present on the web. Considering that in addition to music festivals, there are also many others who valorise other arts, it is evident that the phenomenon is even more important. Moreover, it is significant to emphasize that most of them are strongly connected with the local environment. Maybe, the main reasons of this relation are related to the specific anthropologic features of Italy. In fact, there are several examples where a festival principally represents a driver to support the aggregation and the identity of the local community. To sustain this thesis, there is the fact that many festivals are organized by cultural associations while the firms are in the minority. In this way, the festival becomes a tool for sustainable development of the area because it preserves and promotes the culture and society through the direct participation of local residents. Moreover, it can also contribute to the harmonious development of the local economy. In fact, the observed data shows how widespread the approach is to the music festival to promote other activities, most notably typi- cal food. In our opinion, in Italy the time is ripe to consider festivals as tools in place marketing and tourism development. A fundamental role for the success of the event is played by the organizer. The results show the existence of different types of organizations whose structure become more complex the greater the number of festival editions. It is also evident that if the number of editions increases, also the overall complexity increases, as clearly evident in the case of revenue, expenditure and number of people involved.

The respondents claim to know and use management practices. This statement leads us to believe that the level of entrepreneurship is good despite the organizational structure not being too articulate.

In confirmation we report some findings. Many festivals use a strategic approach, and brand strategies play a key role. They recognize the importance of stakeholders in organizing the festival and in general they are also aware of their influence. In fact, they claim to have a network of relationships. Despite this statement, the results of the research show that the weight and frequency of the relationships are not so obvious.

The analysis of sources of funding shows that festivals are highly dependent on public and private funding. Furthermore, among the few weaknesses that they say to have, there is the low capability to manage cash flow and costs. Those factors highlight how important it is to deepen the knowledge about 
the organization of the event in terms of human resource management, competencies and skills required, and the management tools. Those evidences suggest further researches in this context such as the creation of a general framework useful for researchers to monitor, to evaluate and to compare strategies of the events.

This frame will be also functional to the exigencies of festival's managers who may dispose of a strategic performance management tool for keeping track of the execution of activities.

\section{References}

Allen, J., O'Toole, W., McDonnell, I., and Harris, R. 2002 Festival and Special Event Management. Queensland: John Wiley and Sons Milton.

Andersson, T., and Getz, D.

2008 "Stakeholder management strategies of fes" tivals". Journal of Convention and Event Tourism, 9(3): 199-220.

Arcodia, C., and Robb, A.

2000 "A taxonomy of event management terms". In Allen, J., Harris, R., Jago, L. K. and Veal, A. J. (Eds.), Events Beyond 2000: Setting the Agenda. Proceedings of Conference on Event Evaluation, Research and Education (pp. 154-160). Sydney: Australian Centre for Event Management.

Cunningham, M. T., and Culligan, K.

1990 "Competitiveness through networks of relationships in information technology product markets". In Ford, D. (Ed.), Understanding Business Markets: Interaction, Relationships and Networks. London: Academic Press.

Donaldson, T., and Preston, L. E.

1995 "The stakeholder theory of the corporation: concepts, evidence, and implications". Academy of Management Review, 20(1): 65-91.

Falassi, A.

1987 Time Out of Time: Essays on the Festival. Albuquerque, NM: University of New Mexico Press.

Freeman, R. E.

1984 Strategic Management: A Stakeholder Approach. Boston: Pitman Publishing.

Getz. D.

1991 Festivals, Special Events and Tourism. Reinhold, NY: Van Nostrand.

Getz, D.

2002 "Editorial: On the nature and significance of events studies". Event Management, 7(3): 141142.

Getz, D.
2005 Event Management and Event Tourism. New York: Cognizant Communication.

Getz, D.

2007 Event Studies. Theory, Research and Policy for Planned Events. Oxford: Butterworth Heinemann.

Getz, D.

2008 "Event tourism: definition, evolution, and research". Tourism Management, 29(3): 403-428.

Getz, D., Andersson, T., and Carlsen, J.

2010 "Festival management studies: developing a framework and priorities for comparative and cross-cultural research". International Journal of Event and Festival Management, 1(1): 29-59.

Getz, D., Andersson, T., and Larson, M.

2007 "Festival stakeholder roles: concepts and case studies". Event Management, 10(2/3): 10322.

Gummesson, E.

1996 "Relationship marketing and imaginary organisations: a synthesis". European Journal of Marketing, 30(2): 31-44.

Huxham, C.

1996 "Collaboration and collaborative advantage". In Huxham, C. (Ed.), Creating Collaborative Advantage. London: SAGE Publications Ltd. Merrilees, B., Getz, D., and O'Brien, D.

2005 "Marketing stakeholder analysis: Branding the Brisbane Goodwill Games". European Journal of Marketing, 39(9/10): 1060-1077.

Mitchell, R. K., Agle, B. R., and Wood, D. J.

1997 "Toward a theory of stakeholder identification and salience: defining the principle of who and what really counts". Academy of Management Review, 22(4): 853-886.

Prentice, R., and Andersen, V.

2003 "Festival as creative destination". Annals of Tourism Research, 30(1): 7-30.

Reid, S.

2011 "Event stakeholder management: developing sustainable rural event practices". International Journal of Event and Festival Management, 2(1): 20-36.

Reid, S., and Arcodia, C.

2002 "Understanding the role of the stakeholder in event management". In Jago, L., Deery, R., Allen, J., Hede, A. (Eds.), Events and Place Making. Sydney: Australian Centre for Event Management, UTS.

Richards, G.

2007 Cultural Tourism: Global and Local Perspectives. Binghamton, NY: Haworth Press. 
Sautter, E. T., and Leisen, B.

1999 "Managing stakeholders a tourism planning model". Annals of Tourism Research, 26(2): 312328.

Savage, G., Nix, T., Whitehead, C., and Blair, J.

1991 "Strategies for assessing and managing organizational stakeholders". Academy of Management Executive, 5(2): 51-75.

Wilson, J., and Udall, L.

1982 Folk Festivals: A Handbook for Organization and Management. Knoxville: The University of Tennessee Press.

Wood, D. J., and Gray, B.

1991 "Toward a Comprehensive Theory of Collaboration". Journal of Applied Behavioral Science, 27(2): 139-162.
Recibido:

$15 / 02 / 2011$

Reenviado:

$30 / 09 / 2011$

Aceptado:

$31 / 10 / 2011$

Sometido a evaluación por pares anónimos 